\title{
SABRE-hanke; Kohdun limakalvon geenitoiminta hyvän alkiovastaanottajan tunnistamisessa
}

J. Peippo ${ }^{1}$, T. Tiirikka ${ }^{1}$, M. Räty ${ }^{1}$, V. Ahola ${ }^{1}$, T. Hurme ${ }^{2}$, C. Grosse-Brinkhaus ${ }^{3}$, D. Salilew-Wondim ${ }^{3}$, P. Sørensen ${ }^{4}$ J. Taponen ${ }^{5}$, J. Aro $^{6}$, H. Myllymäki ${ }^{6}$, D. Tesfaye ${ }^{3}$ ja J. Vilkki ${ }^{1}$ :

${ }^{1}$ MTT Biotekniikka- ja elintarviketutkimus, Eläingenomiikka, 31600 Jokioinen, ${ }^{2}$ MTT Palveluyksikkö, Menetelmäpalvelut, 31600 Jokioinen, ${ }^{3}$ Institute of Animal Science, Animal Breeding and Husbandry Group, University of Bonn, 53115 Bonn, Germany, ${ }^{4}$ Department of Genetics and Biotechnology, Faculty of Agricultural Sciences, University of Aarhus, P.O. Box 50, DK-8830 Tjele, Denmark, ${ }^{5}$ Tuotaeläinlääketieteen laitos, Eläinlääketieteellinen tiedekunta, Helsingin yliopisto, 04920 Saarentaus, Alkiokeskus Oy, Urheilutie 6, 01301 Vantaa

\section{Tiivistelmä}

Alkionsiirtoja hyödyntävät paitsi jalostusohjelmat myös maitotilat. Alkiohuuhteluiden avulla hyvistä tuotantoeläimistä voidaan saada useita jälkeläisiä vuodessa karjan muiden eläinten toimiessa alkioiden vastaanottajina, mikä mahdollistaa karjan nopean eläinaineksen parantamisen. Ennen alkionsiirtoa vastaanottajan keltarauhanen tarkastetaan manuaalisesti. Keltarauhanen kehittyy ovulaation seurauksena ja sen tuottama progesteroni-hormoni vaikuttaa kohdun limakalvon toimintaan tehden sen alkion kiinnittymiselle suotuisaksi. Nykyisin keskimäärin joka toinen tuorealkionsiirto johtaa tiinehtymiseen. Tämän tutkimuksen tarkoituksena oli selvittää alkionsiirrosta tiinehtyneiden/poikineiden ja tyhjäksi jääneiden vastaanottajien kohdun limakalvon toimintaa. Tavoitteena oli löytää tiinehtyvän eläimen kohdun limakalvon toiminnalle ominaisia aineenvaihduntareittejä ja mahdollisesti kandidaattigeenejä diagnostiikan työkaluiksi. Tutkimus tehtiin maidontuotannossa olevilla lehmillä. Poikimisen jälkeen alkiovastaanottajien kohdun limakalvosta otettiin näytepalat ensimmäisen näkyvän kiimankierron päivinä $O($ siemennyskiima), 7 ja 14 . Näytepalat pakastettiin $\left(-80^{\circ} \mathrm{C}\right)$. Seuraavan kiimakierron päivänä 7 samaan vastaanottajaan siirrettiin alkio ja alkion kiinnittyminen tarkistettiin kuukauden kuluttua siirrosta. Poikimisten jälkeen pakastetut kohtunäytteet jaettiin poikineiden ja tyhjiksi jääneiden ryhmiin, ja näytteiden geenitoimintaa verrattiin mikrosirutekniikalla, joka mahdollistaa kymmenien tuhansien geenituotteiden samanaikaisen analysoinnin. Vastaanottajista kerättiin lisäksi tuotos- ja hedelmällisyystietoja. Mikrosirututkimuksen perusteella erot poikineiden ja tyhjiksi jääneiden lehmien välillä keskittyivät kiimankierron alkupuoliskolle, jolloin eroja löytyi 64 yksittäisen geenin osalta. Aineenvaihduntareittien osalta kohdun limakalvon toiminnassa todettiin ryhmien välillä eroja $\mathrm{mm}$. rasvahappojen aineenvaihdunnassa ja immuunivasteissa. Tuotos- ja hedelmällisyysominaisuuksien osalta poikineet ja tyhjiksi jääneet alkiovastaanottajat poikkesivat toisistaan kokonaisjalostusarvojen ja rasvatuotosindeksien osalta. Tämä tutkimus on osa EU:n rahoittamaa SABRE-projektia (2006-2010).

Avainsanat: lehmä, tiineys, endometrium, geenitoiminta, Affymetrix mikrosiru, qPCR 


\section{Johdanto}

Maidontuotannon kasvu on johtanut lypsylehmien hedelmällisyyden laskuun. Hedelmällisyys, joka useimmin määritellään tiinehtymisenä, on pitkä biologinen prosessiketju. Hyvään hedelmällisyyteen tarvitaan onnistunut munasolun kypsyminen ja hedelmöityminen sekä onnistunut alkion kehitys ja alkion ja kohdun välinen vuorovaikutus. Tässä tutkimuksessa keskityttiin selvittämään niitä biologisia prosesseja, jotka tekevät kohdun limakalvosta alkion kiinnittymiselle suotuisan maidontuotannossa olevilla lehmillä.

\section{Materiaalit ja Menetelmät}

Lehmien kiimankiertojen käynnistymistä tarkkailtiin poikimisen jälkeen ja kohdun limakalvosta otettiin kudosnäyte ensimmäisen havaitun seisovan kiiman kohdalla (näytteenottopäivä $0=$ siemennyskiima) sekä saman kiimankierron päivinä 7 (näytteenottopäivä 7) ja 14 (näytteenottopäivä 14). Näytepalat puolitettiin ja jäädytettiin välittömästi nestemäisessä typessä. Puolikkaita säilytettiin $80^{\circ} \mathrm{C}$ :ssa geenitoiminnan tutkimuksiin asti. Seuraavan kiimankierron aikana kuhunkin monitoroituun vastaanottajaan pyrittiin siirtämään hyvälaatuinen tuorealkio, josta oli otettu alkion geenitoiminnan tutkimusta varten näytepala eli biopsia. Molempia kiimankiertoja monitoroitiin maidosta tehdyillä progesteronimäärityksillä. Alkiovastaanottajista kerättiin lisäksi hedelmällisyys- ja tuotostietoja.

Kohtunäytteitä yhdistettiin ennen RNA eristystä. Arpomalla muodostettiin viisi poikineiden lehmien poolia ja viisi tyhjiksi jääneiden lehmien poolia (3 lehmää/pooli) kunakin kolmena keruupäivänä. Näytteiden RNA:n eristys, esimonistus ja kaupalliselle Affymetrixin mikrosiruille hybridisointi tehtiin alihankintatyönä AROS Applied Biotechnology A/S:lla Tanskassa. Intensiteetit normalisoitiin Robust Multichip Analysis (RMA) normalisoinnilla, jonka jälkeen poikineiden ja tyhjien välisiä eroja testattiin geeneittäin modifioiduilla t-testillä käyttäen sopivia monivertailumenetelmiä. Koska suurin osa normalisointimenetelmistä on suunnattu erilaisten tautiaineistojen käsittelyyn ihmisellä, päätimme testata erilaisia menetelmiä oman aineistomme mikrosirujen esikäsittelyyn ja normalisointiin. Poikineiden ja tyhjien välisiä eroja testattiin myös geeniryhmittäin. Geeniryhminä käytettiin geeniontologioita (GO) ja geeniverkkoja (KEGG). Lisäksi koko aineistoa tarkasteltiin etsimällä jo olemassa olevaa informaatiota PubMed-tietokannasta käyttäen tiedonlouhinnan menetelmiä. Tulokset visualisointiin käyttäen Genomatix ja Cytoscape ohjelmistoja. Aineisto käsiteltiin alustavasti R/Bioconductor ohjelmalla ja siihen liittyvillä paketeilla (esim. affy, gcrma ja limma). Geenien identifioimiseen ja ryhmittelyyn käytettiin erikseen koodattuja R-paketteja, joissa nauta- ja ihmistietokantojen annotointitietoja liitettiin siruilta saatuun aineistoon. Saaduista geenilistoista etsittiin myös yhtäläisyyksiä eri organismien välillä $(\mathrm{mm}$. ihminen ja hiiri) käyttäen lähtökohtina geeninimeä, ontologiaa sekä sekvenssitietoa. Jatkoanalyyseihin sovellettiin omia Perl-ohjelmia.

\section{Tulokset ja tulosten tarkastelu}

Yhteensä 94 lehmävastaanottajan kohdun limakalvosta otettiin näytepalat alkionsiirtoa edeltävän kiimankierron päivinä 0,7 ja 14. Näihin monitoroituihin vastaanottajiin tehtiin 56 tuorealkionsiirtoa. Lisäksi viikonloppuisin, jolloin tuorealkioita ei ollut saatavana, siirrettiin 38 sulatettua alkiopakastetta ilman biopsiointia. Tuorealkiovastaanottajista tiinehtyi 18 (32 \%), mikä on keskimäärin 10 prosenttiyksikköä vähemmän kuin aiemmassa alkionsiirtotutkimuksessamme (Peippo ym., 2007). Ero aiempaan tutkimukseen johtunee tässä tutkimuksessa kohdusta otetuista näytepaloista. Kaksi luomista todettiin $(4 \%)$. Tuorealkiovastaanottajista poiki $16 \quad(29 \%)$ ja 15 niistä hyväksyttiin mikrosiruanalyyseihin progesteroniprofiloinnin perusteella. Progesteronimäärityksillä varmistettiin, että molemmat kiimankierrot (monitorointi ja alkionsiirto) olivat edustavia. Vastaavasti valittiin 38 tyhjäksi jääneestä tuorealkiovastaanottajasta 15 mikrosiruanalyyseihin. Pakastealkiovastaanottajista poiki $8(21 \%)$. 
Poikineiden alkiovastaanottajien kokonaisjalostusarvot ja rasvatuotos-indeksit olivat tyhjiksi jääneitä alkiovastaanottajia alemmat $(p \leq 0.05)$. Muiden testattujen ominaisuuksien (indeksit: tuotos, valkuaistuotos, utareterveys; energiakorjattu maitotuotos (ECM), ensimmäinen poikiminen, aika poikimisesta siemennyskiimaan) osalta erot eivät olleet poikineiden ja tyhjiksi jääneiden välillä tilastollisesti merkitseviä. Koska maidontuotantoon jalostettujen lehmien on todettu käyttävän jopa 35 \% päivittäisestä energian saannistaan maidon rasvakomponenttien tuottamiseen (Bauman ja Currie 1980) voi korkeampi rasvatuotos osaltaan johtaa poikimisen jälkeiseen negatiiviseen energiataseeseen, jonka tiedetään olevan merkittävä lypsylehmien hedelmällisyyttä alentava tekijä. Esimerkiksi, negatiivisen energiataseen seurauksena hajoavan lihaskudoksen on todettu nostavan $\mathrm{mm}$. plasman ureapitoisuutta (Wathes ym., 2007). Plasman korkea ureapitoisuus alentaa hedelmällisyyttä muuttamalla kohdun olosuhteita (esim. pH) (Bauersachs ym., 2008). Kohdun limakalvon soluviljelmissä ureapitoisuuden nousu lisää $\mathrm{PGF}_{2 \alpha}$ tuotantoa, jolla on todettua haitallisia vaikutuksia tiinehtymiseen ja sen ylläpitoon, lisäksi sen on todettu olevan haitallista alkionkehitykselle.

Yhteensä 30 kohtunäytepoolia hybridisoitiin Affymetrixin nautasirulle, minkä jälkeen erilaisia tilastollisia ja bioinformatiikan menetelmiä hyväksi käyttäen mikrosirujen laatu ja hybridisaatioiden onnistuminen tarkistettiin. Yksi poikkeava mikrosiru jätettiin analyyseistä pois. Verrattaessa yksittäisiä geenejä poikineiden ja tyhjiksi jääneiden vastaanottajalehmien välillä eri ajankohtina, 91 mikrosirulla esiintyvää koetinta (64 geeniä) käyttäytyivät eri tavalla keruupäivänä 0 . Muina yksittäisinä keruupäivinä poikineiden ja tyhjien välillä ei ollut eroja yksittäisten geenien vertailussa käytetyillä kriteereillä (aktiivisuusero $\geq 2, \mathrm{FDR} \leq 0.3$ ). Geeniryhmävertailuissa poikineiden ja tyhjien eläinten välillä havaittiin eroja siinä miten eri geeniryhmät käyttäytyvät eri keruupäivinä. Tulosten varmennukseen kvantitatiivisella PCR:llä (qPCR) valittiin yhteensä 26 geeniä PPAR signalointi- ja arachidonic acid -aineenvaihduntareiteiltä, joihin kiinnostavia yksittäisiä merkitseviä geenejä osui. PPAR signalointireitti osallistuu $\mathrm{mm}$. rasvahappojen aineenvaihduntaan ja arachidonic acid aineenvaihduntareitin syntetisoimien prostaglandiinien ja prostasykliinin vaikutukset välittyvät PPAR signalointireitin kautta (Hatae $\mathrm{T}$ ym., 2001). Varmennuksissa käytetään mikrosiruanalyyseihin käytettyjen näytteiden jäljellä olevia puolikkaita ja pakastealkion vastaanottajina toimineiden lehmien näytteitä, jotka eivät olleet mukana mikrosiruanalyyseissä. Fenotyyppien välisiä riippuvuuksia tutkittiin vertailemalla kolmea eri tilastollista menetelmää: GSEA, PCA ja kanoninen analyysi. Menetelmät havaitsivat merkittäviä eroja todennäköisyysarvoissa eri fenotyyppien (energiakorjattu maitotuotos, maitorasvakilo-indeksi) välisissä geenilistoissa. Lisäksi tutkittiin laskennallisesti löydettyjen eroavien geenien promoottorirakennetta sekä sekvenssin konservoituneisuutta. Tuloksia verrattiin muiden vastaaviin tutkimuksiin käyttäen GEO (Gene Expression Omnibus) tietokantaa.

\section{Johtopäätökset}

Useiden näytepalojen otto alkiovastaanottajien kohdun limakalvosta alkionsiirtoa edeltäneen kiimankierron aikana pudotti tiineysprosenttia odotetusti. Lehmäaineiston ryhmien sisäinen vaihtelu heikensi ryhmien välisten erojen merkitsevyyksiä, mutta toisaalta lehmävastaanottajien käytön etuna oli ainutlaatuinen mahdollisuus yhdistää hedelmällisyys- ja tuotostietoja analyyseissä. Kirjallisuuskatsaus ja geenitutkimus paljastivat useiden interaktioverkkojen sekä signalointireittien olemassaolon geenilistoissa, myös fenotyyppien välillä. 


\section{Kirjallisuus}

Bauersachs, S., Mitko, K., Ulbrich, S.E., Blum, H., Wolf, E. 2008. Transcriptome studies of bovine endometrium reveal molecular profiles characteristic for specific stages of estrous cycle and early pregnancy. Exp Clin Endocrinol Diabetes 116: 1-14.

Bauman, D.E., Currie, W.B. 1980. Partitioning of nutrients during pregnancy and lactation: A review of mechanisms involving homeostasis and homeorhesis. J Dairy Sci 63: 1514-29.

Hatae, T., Wada, M, Yokoyama, C., Shimonishi, M., Tanabe, T. 2001. Prostacyclin-dependent apotosis mediated by PPAR $\delta$. J Biol Chem 276: 46260-7.

Peippo, J., Viitala, S., Virta, J., Räty, M., Tammiranta, N., Lamminen, T., Aro, J., Myllymäki, H., Vilkki, J. 2007. Birth of correctly genotyped calves after multiplex marker detection from bovine embryo microblade biopsies. Mol Reprod Dev 74: 1373-8.

Wathes, D.C., Cheng, Z., Bourne, N., Taylor, V.J., Coffey, M.P., Brotherstone, S. 2007. Differences between primiparous and multiparous dairy cows in the inter-relationships between metabolic traits, milk yield and body condition score in the periparturient period. Dom Anim Endocrinol 33: 203-245. 